\title{
In vitro evaluation of the association of chitosan and cashew nut shell liquid as additives for ruminants
}

\section{Avaliação in vitro da associação de quitosana e líquido da casca da castanha de caju como aditivos para ruminantes}

PEREIRA, Daniele Cristina ${ }^{1 *}$ (D) GOES, Rafael Henrique de Tonissi e Buschinelli de ${ }^{2}$; MARTINEZ, Antônio Campanha ${ }^{3}$ (D) GANDRA, Jefferson Rodrigues ${ }^{2}$ (D) PRESENDO, Eduardo ${ }^{4}$ (D) SANTOS, Mariana Viegas $\operatorname{dos}^{2}$ (D) OLIVEIRA, Raquel Tenório ${ }^{2}$ (D) SILVA, Nayara Gonçalves da ${ }^{2}$; RIBEIRO, Max Gimenez ${ }^{3}$ (D) ALVEZ, Jefferson Leonardo Rocha ${ }^{3}$ (D)

\footnotetext{
${ }^{1}$ Universidade Estadual de Maringá. Centro De Ciências Agrárias. Programa de Pós-Graduação em Produção Sustentável e Saúde Animal. Umuarama. PR, Brasil.

${ }^{2}$ Universidade Federal da Grande Dourados. Faculdade de Ciências Agrárias. Dourados. MS, Brasil.

${ }^{3}$ Universidade Estadual de Maringá. Centro De Ciências Agrárias Departamento de Medicina Veterinária. Umuarama. PR, Brasil.

${ }^{4}$ Médico Veterinário, Especialista em Pecuária leiteira. Uberaba. MG, Brasil.

*Endereço para correspondência: daniele_cristina92@hotmail.com
}

\section{ABSTRACT}

This study evaluated the in vitro digestibility of nutrients from different diets added with chitosan $(\mathrm{Q})$, technic cashew nut shell liquid (LCC) and the association of Q and LCC. The treatments used consisted of 4 diets (forage: concentrate ratio of 100: 0 , 50:50, 40:60 and 20:80) associated with 4 additives (control, chitosan, LCC and the association of $\mathrm{Q}+\mathrm{LCC}$ ), totaling 16 treatments, in a $4 \times 4$ factorial randomized block design. The dosages used were: Control (without additives), LCC $(600 \mathrm{mg} / \mathrm{kg} \mathrm{DM})$, Chitosan (900mg/kg DM), and LCCQ $(600 \mathrm{mg} / \mathrm{kg} \mathrm{LCC} \mathrm{DM}+900 \mathrm{mg} / \mathrm{kg}$ Chitosan DM). In the laboratory, samples were analyzed for IVDMD, IVNDFD, IVCPD, $\mathrm{pH}$ and RAN (ruminal ammonia nitrogen). For $\mathrm{pH}$ and RAN analyses, samples were taken at 0,2, 4, 6 and 8 hours after incubation. The results showed higher digestibility of DM, NDF and CP for diets with chitosan and technic cashew nut shell liquid alone and higher $\mathrm{pH}$ and RAN values in the diets containing the two additives. The association of additives brings better results for animal nutrition and increases ruminant productivity.

Keywords: Anacardium occidentale, chemical analysis, natural additives, ruminal modulation

\section{RESUMO}

Objetivou-se avaliar no presente trabalho a digestibilidade in vitro de nutrientes de diferentes dietas com a adição de quitosana (Q), líquido da casca da castanha de caju (LCC) e a associação entre Q e LCC. Os tratamentos utilizados foram constituídos de 4 dietas (relação volumoso:concentrado, 100:0, 50:50, 40:60 e 20:80) associadas com 4 aditivos (controle, quitosana, LCC e a associação entre ambos $\mathrm{Q}+\mathrm{LCCt}$ ), totalizando 16 tratamentos,distribuídas em delineamento em blocos ao acaso em esquema fatorial $4 \mathrm{x} 4$. As dosagens utilizadas foram: Controle (sem adição de aditivos), LCC (600mg/Kg de MS), Quitosana (900mg/Kg de MS), e o LCCQ $(600 \mathrm{mg} / \mathrm{Kg}$ de MS de LCC + $900 \mathrm{mg} / \mathrm{Kg}$ de MS de quitosana). No laboratório foram avaliados a DIVMS, DIVFDN, DIVPB, $\mathrm{pH}$ e NAR (nitrogênio amoniacal ruminal). Para as análises de $\mathrm{pH}$ e NAR, foram coletadas amostras nas horas $0,2,4,6$ e 8 após a incubação. Os resultados encontrados mostraram maior digestibilidade de MS, FDN e PB para dietas que receberam quitosana e líquido da casca da castanha de caju de forma isolada e maiores valores de $\mathrm{pH}$ e NAR nas dietas que receberam os dois aditivos associados. Conclui-se que a associação dos aditivos traz melhores resultados para a nutrição animal e eleva a produtividade dos ruminantes.

Palavras-chave: Aditivos naturais, Anacardium occidentale, análise bromatológica, modulação ruminal 


\section{INTRODUCTION}

Research shows that when ruminant feed is based only on forage, their products are not high quality, whether meat or milk, justifying the search for new foods that improve nutrition. The most used food to supplement animal nutrition is concentrate, however, its cost is very high and so it is also used additives, whose function is to maximize animal production and reduce costs (OLIVEIRA et al., 2012a).

One of the most commonly used additives is ionophore antibiotics, which modulate ruminal fermentation, decreasing the number of gram-positive and increasing gram-negative bacteria, improving propionate production and reducing acetic, lactic acid and methane (SHINKAI et al., 2012). Nevertheless, after 30 years of using ionophore antibiotics, the European Union adopted the principle of prevention and banned their application in animal feed from the end of 2005, thinking about reducing the risks of antimicrobial resistance caused by the long-term use of this additive (RATCLIFF, 2003).

Recently, Goiri et al. (2009a) proposed the use of chitosan as an additive in ruminant nutrition, acting on ruminal modulation, improving animal performance, similar to ionophore antibiotics. However, Tang et al. (2010) described the need for minimal doses of chitosan to inhibit the action of certain groups of bacteria.

Cashew nut shell liquid is described as a functional oil, with important antimicrobial action on gram-positive bacteria, similar to chitosan. Studies indicate that the use of cashew nut shell liquid improves the nutrition of beef and dairy cattle, sheep and goats (YANG et al., 2010; ANASSORI et al., 2011; TAGER \& KRAUSE, 2011; TEKIPPE et al., 2011; GERACI et al., 2012).

According to Jacaúna (2016), in vitro experiments with the use of chitosan, increased in vitro dry matter digestibility
(DIVMS) and reduced in vitro crude protein digestibility (DIVPB). Cashew nut shell liquid (LCC) at $550 \mu \mathrm{g} / \mathrm{mL}$ in diets containing $30 \%$ forage can reduce the production of methane, acetate and butyrate and increase propionate concentration (WATANABE et al. 2010). According to Diaz et al. (2018), the inclusion level of up to $0.5 \mathrm{~g} / \mathrm{kg}$ technical LCCDM increased the IVDMD, and values higher than this resulted in a decrease in IVDMD.

Based on this, the goal of this study was to evaluate in vitro the inclusion of chitosan and technical cashew nut shell liquid in ruminant diets, regarding nutrient digestibility and fermentation parameters.

\section{MATERIAL AND METHODS}

The experiment was carried out in two steps, conducted in the facilities of the Oilseed by-product Laboratory (LACO IMPAC 2 - FINEP/UFGD) and Animal Nutrition (LANA) of the Faculty of Agricultural Sciences, Federal University of Grande Dourados, Dourados, State of Mato Grosso do Sul. All procedures were performed in accordance with the rules of the Ethics Committee on Animal Use (CEUA), belonging to the Federal University of Grande Dourados, protocol 023/2015 - CEUA/UFGD.

Ruminal fluid donors were two adult male, castrated, crossbred cattle, with average weight of $350 \mathrm{~kg}$, provided with ruminal cannula, kept in individual stall $(3 \times 6 \mathrm{~m})$. The treatments consisted of 4 diets associated with 4 additives (control, Q chitosan, LCC -technical cashew nut shell liquid and the association of Q + LCC chitosan and technical cashew nut shell liquid), totaling 16 treatments $(4 \times 4=16)$.

The additives used were: Q: chitosan (deacetylation degree $>850 \mathrm{~g} / \mathrm{kg}, 0.32 \mathrm{~g} / \mathrm{mL}$ density, pH 7.90, <200cPs viscosity, $1.35 \mathrm{~g} / 100 \mathrm{~g}$ total ash and $9.3 \mathrm{~g} / 100 \mathrm{~g}$ loss on drying); LCC: technical cashew nut shell 
liquid (10.03 mg/g anacardic acid; 540.77 $\mathrm{mg} / \mathrm{g}$ cardanol; $102.34 \mathrm{mg} / \mathrm{g}$ cardol; and $19.17 \mathrm{mg} / \mathrm{g}$ 2-methylcardol); Q + LCC: association of chitosan and cashew nut shell liquid; plus control (C), without additives.

LCC analysis was performed on a HighPerformance Liquid Chromatograph (Varian 210) diode array detector (DAD) and Star WS software (Workstation 2.0). The column used was $\mathrm{C} 18$ reverse phase (25 cm x $4.6 \mathrm{~mm} \times 5 \mu \mathrm{m})$ (Phenomenex). Elution was performed using acetonitrile/water/acetic acid gradient system $(66 / 33 / 2 \quad$ v: v: v) (A) and tetrahydrofuran (B), which started elution with $10 \% \mathrm{~B}$ and in 40 minutes reached $100 \%$ B. The pump flow rate was $1 \mathrm{~mL} / \mathrm{min}$ and the injected volume was $20 \mu \mathrm{L}$. The analysis was conducted at $22^{\circ} \mathrm{C}$, both in the preparation of the analytical curve and in the product analysis, and injections were performed in triplicate. The product was solubilized in acetonitrile/water $(66 / 35 \mathrm{v}$ : v) providing a final concentration of $1000 \mu \mathrm{g} / \mathrm{mL}$. The external standard curves employed to quantify anacardic acid, cardanol, 2methylcardol and cardol in the LCC product were prepared employing compounds of $97 \%$ purity at concentrations $10-100 \mu \mathrm{g} / \mathrm{mL}$. Results were expressed in $\mathrm{mg} / \mathrm{g}$ sample obtained from an external standardization curve with a correlation coefficient of 0.9992 for all compounds analyzed.

The diets consisted of Tifton 85 hay as forage; $60 \%$ ground corn and 40\%soybean meal as concentrate, both on a dry matter basis (Table 1). Four forage: concentrate (F: C) ratios were used 100:0, 50:50, 40:60 and 20:80.

Table 1.Chemical composition of ingredients (\% DM) used in experimental diets.

\begin{tabular}{lllllll}
\hline Ingredient & DM & ASH & CP & NDF & ADF & EE \\
\hline Tifton 85hay & 86.81 & 10.13 & 13.03 & 86.21 & 25.33 & 2.86 \\
& & & & & & \\
Corn & 74.74 & 2.74 & 10.50 & 71.14 & 5.87 & 30.07 \\
& & & & & \\
& & & & & \\
Soybeanmeal & 77.60 & 7.74 & 40.16 & 48.27 & 17.18 & 17.28 \\
\hline DM = Dry Matter, CP = Crude Protein & & & \\
NDF = Neutral Detergent Fiber \\
ADF = Acid Detergent \\
Fiber and EE = Ether Extract.
\end{tabular}

The methodology described by Tilley \& Terry (1963) modified by Holden et al. (1999) to determine in vitro dry matter digestibility (IVDMD) using an in vitro incubator (TE-150 Tecnal $^{\circledR}$ - Piracicaba, Brasil). Bags of TNT (non-woven fabric) $100 \mathrm{~g} / \mathrm{m}^{2}$ were made to a size of $5.0 \times 5.0$ $\mathrm{cm}$ and washed in acetone as described by Casali et al. (2008). The samples were ground through a $2 \mathrm{~mm}$ sieve, weighed
$(0.5 \mathrm{~g})$ and placed inside the bags, respecting the evaluated $\mathrm{F}$ : $\mathrm{C}$ ratio (100: 0 , 50:50, 40:60 and 20:80).

For incubation, Kansas buffer solution (MARTEN \& BARNES, 1980; SILVA \& QUEIROZ, 2002) was prepared as follows: Solution A (grams/L): $10.0 \mathrm{~g} \mathrm{KH}_{2} \mathrm{PO}_{4} ; 0.5$ g $\quad \mathrm{MgSO}_{4} 7 \mathrm{H}_{2} \mathrm{O} ; 0.5 \mathrm{~g} \quad \mathrm{NaCl} ; 0.1 \mathrm{~g}$ $\mathrm{CaCl}_{2} 2 \mathrm{H}_{2} \mathrm{O} ; 0.5 \mathrm{~g}$ urea, and solution $\mathrm{B}$ (grams/100mL): $15.0 \mathrm{~g} \mathrm{Na} 2 \mathrm{CO} 3 ; 1.0 \mathrm{~g}$ 
$\mathrm{Na}_{2} \mathrm{~S} .9 \mathrm{H}_{2} \mathrm{O}$. Prior to incubation, solution $\mathrm{B}$ was mixed with solution $\mathrm{A}$, at a 1: 5 proportion, until the mixture reached $\mathrm{pH}$ 6.8 and always at a constant temperature of $39^{\circ} \mathrm{C}$

For IVDMD determination, the two incubators were previously turned on (temperature and rotation) to maintain the temperature stability of the digestion jars $\left(39^{\circ} \mathrm{C}-41^{\circ} \mathrm{C}\right)$. The buffer solution used was kept in a water bath, at a temperature of $39^{\circ} \mathrm{C}$, and the materials used to collect rumen fluid (beakers and thermoses) were washed with water heated to a temperature close to $39^{\circ} \mathrm{C}$.

Two liters of ruminal fluid were collected per animal, always in the morning, before the first meal, directly from the rumen via rumen cannula. Soon after, the ruminal fluid was filtered through four layers of cheesecloth and transferred to preheated thermos, purged with $\mathrm{CO}_{2}$ and hermetically sealed.

To start the incubation, one jar at a time was taken from the incubator, where 16 TNT bags were placed, 4 bags of each forage: concentrate ratio, randomly distributed on both sides of the jar partition, and other 2 bags without sample (blank) was then added to the buffer solution $(1600 \mathrm{~mL})$ and ruminal fluid (400mL), applying the $\mathrm{CO}_{2}$ for thirty seconds and closing the jar lid, which was returned to the incubator.

Each jar contained all $\mathrm{F}$ : $\mathrm{C}$ ratios and the doses determined as recommended by Dias et al (2017) and Diaz et al (2018). The first jar was the control (C), without additives, the second with $0.11 \mathrm{~g}$ chitosan - Q $(900 \mathrm{mg} / \mathrm{kg} \mathrm{DM})$, the third with the addition of $0.08 \mathrm{~g}$ technical cashew nut shell liquid - LCC (600mg/kg DM), and the fourth with $0.11 \mathrm{~g}$ chitosan $+0.08 \mathrm{~g}$ technical cashew nut shell liquid - $\mathrm{Q}+$ LCC $(900 \mathrm{mg} / \mathrm{kg}$ Q DM + 600mg/kgLCC $\mathrm{DM})$.

Incubation was performed in two stages, the first is described as a fermentative phase, with ruminal digestion lasting 48 hours under controlled temperature (39$41^{\circ} \mathrm{C}$ ) and continuous rotation. The second is called the chemical phase, simulating abomasum digestion, where each jar was taken from the incubator and added with $40 \mathrm{~mL}$ hydrochloric acid $(6 \mathrm{~N} \mathrm{HCl})$ and 8 grams pepsin (Sigma 1: 10000) and then returned to incubation. This procedure was repeated in all jars, as described by Holden (1999). Incubation continued for a further 24 hours under controlled temperature and continuous stirring. At the end of the incubation, all the bags were removed from the jars and washed in running water, followed by oven drying $\left(55^{\circ} \mathrm{C}\right)$, and after 12 hours were weighed.

To obtain the IVDMD, IVNDFD and CPIVD, we calculated the difference in the amount of nutrients in the sample before and after incubation.

The foods composing the evaluated diets were ground in a Wiley mill with a $1 \mathrm{~mm}$ sieve to determine the dry matter (DM), crude protein $(\mathrm{CP})$, mineral matter $(\mathrm{MM})$ and ether extract (EE), according to methodologies described by AOAC (1990). Fractions of neutral detergent fiber (NDF), acid detergent fiber (ADF) were determined by the methodology of Van Soest et al. (1991) using the Tecnal ${ }^{\circledR}$ fiber analyzer (TE-149) sequentially using bags $(5.0 \times 5.0 \mathrm{~cm})$ made of non-woven fabric $\left(100 \mathrm{~g} / \mathrm{m}^{2}\right)$ (Casali et al., 2008). For the determination of NDF, $25 \mathrm{~mL}$ thermostable amylase was added at the beginning of the boil.

In the second part of the experiment, ruminal fluid samples were collected for analysis of rumen ammonia nitrogen (RAN) and $\mathrm{pH}$ measurement using the digital $\mathrm{pH}$ meter $(\mathrm{pH}$ 1500, Instrutherm, São Paulo, Brazil). Samples were taken with the caps of the jug incubated through valves and a three-way Bunsen-type system, which allowed the release of gases produced during fermentation (HOLDEN, 1999). 
During incubation, the ruminal fluid was collected at 2-hour intervals, starting at time 0 (zero), followed by times 2, 4, 6 and 8 , totaling 5 collections throughout the day. This procedure was performed in all incubations. In each collection, $30 \mathrm{~mL}$ buffered ruminal fluid was taken, of which $10 \mathrm{~mL}$ were used immediately after collection to measure the $\mathrm{pH}$, with the help of a digital $\mathrm{pH}$ meter, another $10 \mathrm{~mL}$ were stored in plastic pots containing $1 \mathrm{~mL}$ hydrochloric acid $(\mathrm{HCl})$ 1: 1 , in order to stop fermentation and $\mathrm{pH}$ reduction, avoiding RAN volatilization.

To determine the RANcontent, the samples were previously centrifuged at 3,000 rpm for 15 minutes, in duplicate, then $2 \mathrm{~mL}$ supernatant was collected and evaluated by the micro-Kjeldahl technique, with the addition of potassium hydroxide, according to methodology described by Detmann et al. (2012).

All statistical analyses were performed in $\mathrm{SAS}^{\circledR} 9.2$ (2009). Data collected from the analyses were compared with the control using Tukey's test ( $\alpha=0.05$ probability).

The experiment was a $4 \times 4$ factorial randomized block design, totaling 16 treatments (4 diets $\mathrm{x} 4$ additives).

The mathematical model used was: $Y_{\mathrm{ij}}=\mu$ $+\mathrm{B}_{\mathrm{k}}+\mathrm{D}_{\mathrm{i}}+\mathrm{L}_{\mathrm{j}}+\mathrm{DL}_{\mathrm{ij}}+\mathrm{e}_{\mathrm{ij}} ; \quad \mathrm{Y}_{\mathrm{ij}}=\mu+\mathrm{D}_{\mathrm{i}}$ $+\mathrm{L}_{\mathrm{j}} / \mathrm{D}_{\mathrm{i}}+\mathrm{e}_{\mathrm{ij}}$; where: $\mathrm{k}=$ blocks (from 1 to 4 ); $\mathrm{i}=$ Diet (from 1 to 4 ); $\mathrm{j}=$ Levels of additives (from 1 to 4 ); $D_{i}=$ effect of the diet, from 1 to $4 ; \mathrm{L}_{\mathrm{j}}=$ Main effect of the additive; $\mathrm{D}_{\mathrm{ij}}=$ Effect of the interaction of diet and additives; $\mathrm{L}_{\mathrm{j}} / \mathrm{D}_{\mathrm{i}}=$ Effect of additives within the diet, when significant interaction; and $\mathrm{e}_{\mathrm{ijk}}=$ random effect of the error, associated with each observation, supposing that NID $\left(0 ; \sigma^{2}\right)$.

It was also used the split plot arrangement, where the plot is the diet, composed of 4 forage: concentrate ratios (100: 0, 50:50,
40:60 and 20:80) and the additives C, Q, LCC and Q + LCC, and the split consisted of the sample collection times (hour $0,2,4$, 6 , and 8).

The linear model for the split-plot experiment in a randomized block design is given by: $\mathrm{Y}_{\mathrm{ijk}}=\mu+\tau_{\mathrm{i}}+\gamma_{\mathrm{k}}+(\tau \gamma)_{\mathrm{ik}}+\beta_{\mathrm{j}}+$ $(\tau \beta)_{\mathrm{ij}}+(\tau \beta \gamma)_{\mathrm{ijk}},+\mathrm{e}_{\mathrm{ijk}}$ : $\mathrm{i}=1,2, \ldots$, a $\mathrm{j}=$ $1,2, \ldots, \mathrm{b} \mathrm{k}=1,2, \ldots, \mathrm{r}$. Where: $\mathrm{Y}_{\mathrm{ijk}}$ is the value observed in $\mathrm{i}$-th treatment, $\mathrm{k}$-th block and $j$-th subplot; $\mu$ is a constant; $\tau_{i}$ is the effect of the i-thdiet; $\gamma_{k}$ is the effect of $k$-th block; $(\tau \gamma)_{\mathrm{ik}}$ is the residue of the plot; $\beta_{\mathrm{j}}$ is the effect of $\mathrm{j}$-th mineral supplement; $(\tau \beta)_{\mathrm{ij}}$ is the interaction ofi-thdiet and $\mathrm{j}$-th mineral supplement; $(\tau \beta \gamma)_{\mathrm{ijk}}$ is the residue of the subplot and $\mathrm{e}_{\mathrm{ijk}}=$ random effect of the error, associated with each observation, supposing that NID $\left(0 ; \sigma^{2}\right)$.

All collected data were broken down into orthogonal polynomials, where analysis of variance and regression was allowed by the PROC MIXED command of SAS ${ }^{\circledR} 9.2$ (2009), according to their distributions. When the interactions are significant, they will be broken down, studying one effect within the other and analyzed using the regression model.

\section{RESULTS AND DISCUSSION}

IVDMD was influenced only by the F: C ratio (Table 2), with an increasing linear trend with increasing proportion of concentrate in the diet. DIVMS values in chitosan treatment coincided with studies conducted by Wencelová et al. (2014), who reported that the addition of chitosan decreases the digestibility of DM and NDF in high forage diets. Jacaúna (2016) found that chitosan inclusion in the diet favored the reduction of IVDMD regardless of the level of additive, especially in diets composed of $100 \%$ forage. 
Table 2:In vitro dry matter digestibility of experimental diets.

\begin{tabular}{lllllll}
\hline \multirow{2}{*}{ Additive* $^{*}$} & \multicolumn{2}{l}{ Diets (F:C)\# } & & & \\
\cline { 2 - 4 } & $100: 0$ & $50: 50$ & $40: 60$ & $20: 80$ & Mean & SEM \\
\hline Control & 0.62 & 0.76 & 0.83 & 0.87 & 0.77 & 0.7945 \\
Chitosan & 0.62 & 0.79 & 0.84 & 0.89 & 0.78 & 0.8012 \\
LCC & 0.60 & 0.77 & 0.84 & 0.88 & 0.78 & 0.8078 \\
Q+LCC & 0.58 & 0.77 & 0.82 & 0.87 & 0.77 & 0.7945 \\
\hline Mean $^{1}$ & 0.60 & 0.77 & 0.83 & 0.87 & &
\end{tabular}

SEM: Standard Error of the Mean. *Additive $(\mathrm{P}=0.3096)$; \#diet $(\mathrm{P}<0.001)$, interaction additive $\mathrm{X}$ $\operatorname{diet}(\mathrm{P}=0.9878)$.

${ }^{1} \mathrm{Y}=0.087 \mathrm{x}+0.55, \mathrm{r}^{2}=0.89$

Mean values followed by lowercase letters in the same row do not differ by Tukey's test.

Mean values followed by capital letters in the same column do not differ by Tukey's test.

Goiri et al. (2009a, b) observed a reduction in in vitro digestibility of diets with chitos an and was lower for exclusively forage diets than those with the addition of concentrate. This result can be explained by changes in diet composition, where diets containing concentrate present lower NDF content and higher CP content.

For IVNDFD(Table 3), there was no effect for $\mathrm{F}$ : $\mathrm{C}$ ratio $(\mathrm{P}<0.108)$, additive use $(\mathrm{P}=$ $0.8089)$ and interaction $(\mathrm{P}=0.9657)$. In IVNDFD, it is possible to observe that the highest mean value was observed in diets with chitosan (0.61). The control diet and the one with LCC remained the same; however, the Q+LCC association presented the lowest values (0.42). The association $\mathrm{Q}+\mathrm{LCC}$ presented the lowest IVDMD rate, as well as the diets added with LCCQ had the lowest rate of IVNDFD compared to the diet containing only chitosan; However, for CPIVD, chitosan diet presented higher digestibility rate than LCC (Table 4).

Table 3: In vitro neutral detergent fiber digestibility of experimental diets.

\begin{tabular}{ccccccc}
\hline & \multicolumn{7}{c}{ Diets (F:C)\# } & & \\
\cline { 2 - 5 } Additive & $100: 0$ & $50: 50$ & $40: 60$ & $20: 80$ & Mean & SEM \\
\hline Control & 0.59 & 0.47 & 0.65 & 0.55 & $0.56 \mathrm{~A}$ & 0.044 \\
Chitosan & 0.61 & 0.60 & 0.64 & 0.58 & $0.61 \mathrm{~A}$ & 0.046 \\
LCC & 0.61 & 0.50 & 0.53 & 0.62 & $0.56 \mathrm{~A}$ & 0.035 \\
Q+LCC & 0.46 & 0.35 & 0.36 & 0.52 & $0.42 \mathrm{~A}$ & 0.047 \\
\hline Mean & $0.57 \mathrm{a}$ & $0.48 \mathrm{a}$ & $0.55 \mathrm{a}$ & $0.57 \mathrm{a}$ & \\
\hline SEM: Standard Error of the Mean. *Additive $(\mathrm{P}=0.8089) ; \#$ diet $(\mathrm{P}=0.1080)$, interaction additive X diet \\
(P=0.9657).
\end{tabular}

Mean values followed by lowercase letters in the same row do not differ by Tukey's test. Mean values followed by capital letters in the same column do not differ by Tukey's test.

In chitosan-supplemented sheep, Goiri et al. (2010b) observed that NDF digestibility is reduced compared to animals receiving non-supplemented diets. This result is explained by changes in rumen fermentation patterns, where the addition of chitosan (> 85\% deacetylation) leads to a reduction in protozoan activity by up to $56 \%$, improving rumen bacteria production and fermentable organic matter (BELANCHE et al, 2015). 
There was effect of the diet $(\mathrm{P}<0.001)$ on CPIVD (Table 4), however, no effect of interaction $(\mathrm{P}=0.9567)$ and additive $(\mathrm{P}=$ $0.8809)$.

Table 4: In vitro crude protein digestibility of experimental diets.

\begin{tabular}{|c|c|c|c|c|c|c|}
\hline \multirow[b]{2}{*}{ Additive } & \multicolumn{4}{|c|}{ Diets $(\mathrm{F}: \mathrm{C}) \#$} & \multirow[b]{2}{*}{ Mean } & \multirow[b]{2}{*}{ SEM } \\
\hline & 100:0 & $50: 50$ & $40: 60$ & $20: 80$ & & \\
\hline Control & 0.22 & 0.36 & 0.50 & 0.64 & 0.43 & 0.0405 \\
\hline Chitosan & 0.20 & 0.39 & 0.57 & 0.76 & 0.48 & 0.0379 \\
\hline LCC & 0.18 & 0.40 & 0.48 & 0.69 & 0.44 & 0.0389 \\
\hline $\mathrm{Q}+\mathrm{LCC}$ & 0.20 & 0.33 & 0.52 & 0.52 & 0.39 & 0.0389 \\
\hline Mean & 0.20 & 0.37 & 0.52 & 0.65 & & \\
\hline
\end{tabular}

SEM: Standard Error of the Mean. *Additive $(\mathrm{P}=0.8809)$; \#diet $(\mathrm{P}<0.001)$, interaction additive $\mathrm{X}$ diet $(\mathrm{P}=0.9567)$.

Mean values followed by lowercase letters in the same row do not differ by Tukey's test.

Mean values followed by capital letters in the same column do not differ by Tukey's test.

For CPIVD, the highest mean value was observed for the diet with a $\mathrm{F}$ : $\mathrm{C}$ ratio of 20:80 and the lowest mean value for the $F$ : $\mathrm{C}$ ratio of 100: 0 . The mean CPIVD of chitosan treatment was higher and the lowest mean was verified in $\mathrm{Q}+\mathrm{LCC}$ treatment. Reduction in forage provided a linear increasing effect $(y=0.15 x+0.06$; $\mathrm{r}^{2}=0.99$ ) for CPIVD.

According to Van Der Werf et al. (1996), when the crude protein digestibility rate is lower, there is better nitrogen maintenance and elevation of amino acids in the small intestine, resulting larger amounts of amino acids to be used in reproduction, muscle and milk protein. Nevertheless, in in vitro studies, Diaz et al. (2018)found that the inclusion of up to $0.5 \mathrm{~g} / \mathrm{kg} \mathrm{LCC}$ DM increased IVDMD, and values higher than this reduced IVDMD.

As for $\mathrm{pH}$ (Table 5), there was an effect of the diet $(\mathrm{P}<0.001)$, interaction $(\mathrm{P}<0.001)$ and additive $(\mathrm{P}<0.001)$. The highest mean $\mathrm{pH}$ was registered in the Q+LCC treatment, followed by the chitosan, LCC and control, with a difference of $0.43 \%$ between the highest and lowest values. Among the diets, the highest mean $\mathrm{pH}$ was found for the $\mathrm{F}$ : $\mathrm{C}$ ratio of 100: 0, followed by 40:60, 50:50 and 20:80. There was no variation in linear effect and quadratic effect in any of the treatments.

Table 5: Values of $\mathrm{pH}$ obtained after collection in the digestor jars.

\begin{tabular}{|c|c|c|c|c|c|c|c|c|}
\hline \multirow[b]{2}{*}{ Additive } & \multicolumn{4}{|l|}{ Diets } & \multirow[b]{2}{*}{ Mean } & \multirow[b]{2}{*}{ SEM } & \multicolumn{2}{|l|}{$\mathrm{P}$ value } \\
\hline & $100: 0$ & $50: 50$ & $40: 60$ & $20: 80$ & & & $\mathrm{~L}$ & Q \\
\hline Control & 6.97 & 6.69 & 6.68 & 5.87 & $6.55 d$ & 0.1846 & 0.0069 & 0.0050 \\
\hline Chitosan & 7.03 & 6.67 & 6.71 & 6.35 & $6.69 b$ & 0.1270 & 0.0078 & 0.0249 \\
\hline $\mathrm{LCC}$ & 7.01 & 6.44 & 6.74 & 6.23 & $6.60 c$ & 0.1516 & 0.0141 & 0.0490 \\
\hline $\mathrm{Q}+\mathrm{LCC}$ & 6.95 & 6.48 & 6.85 & 6.52 & $6.70 \mathrm{a}$ & 0.1102 & 0.0675 & 0.1833 \\
\hline Mean & $6.98 \mathrm{a}$ & $6.57 \mathrm{c}$ & $6.74 b$ & $6.24 d$ & 6.63 & 0.1433 & & \\
\hline
\end{tabular}


With extending incubation time, the $\mathrm{pH}$ values decreased (Figure 1); $\mathrm{pH}$ in the first hours (hour 0,2 and 4) was neutral in all treatments, decreasing soon after hour 4 , with values between 6.5 and 6.3 at hour 6 . At hour 8, the $\mathrm{pH}$ remained below 6.0, except for $\mathrm{Q}+\mathrm{LCC}$ treatment. Values of $\mathrm{pH}$ below 6.0 reduce the activity of microorganisms; in the chitosan and LCC treatments, values were between 5.9 and 5.6 respectively and the control treatment had the lowest $\mathrm{pH}, 5.5$.

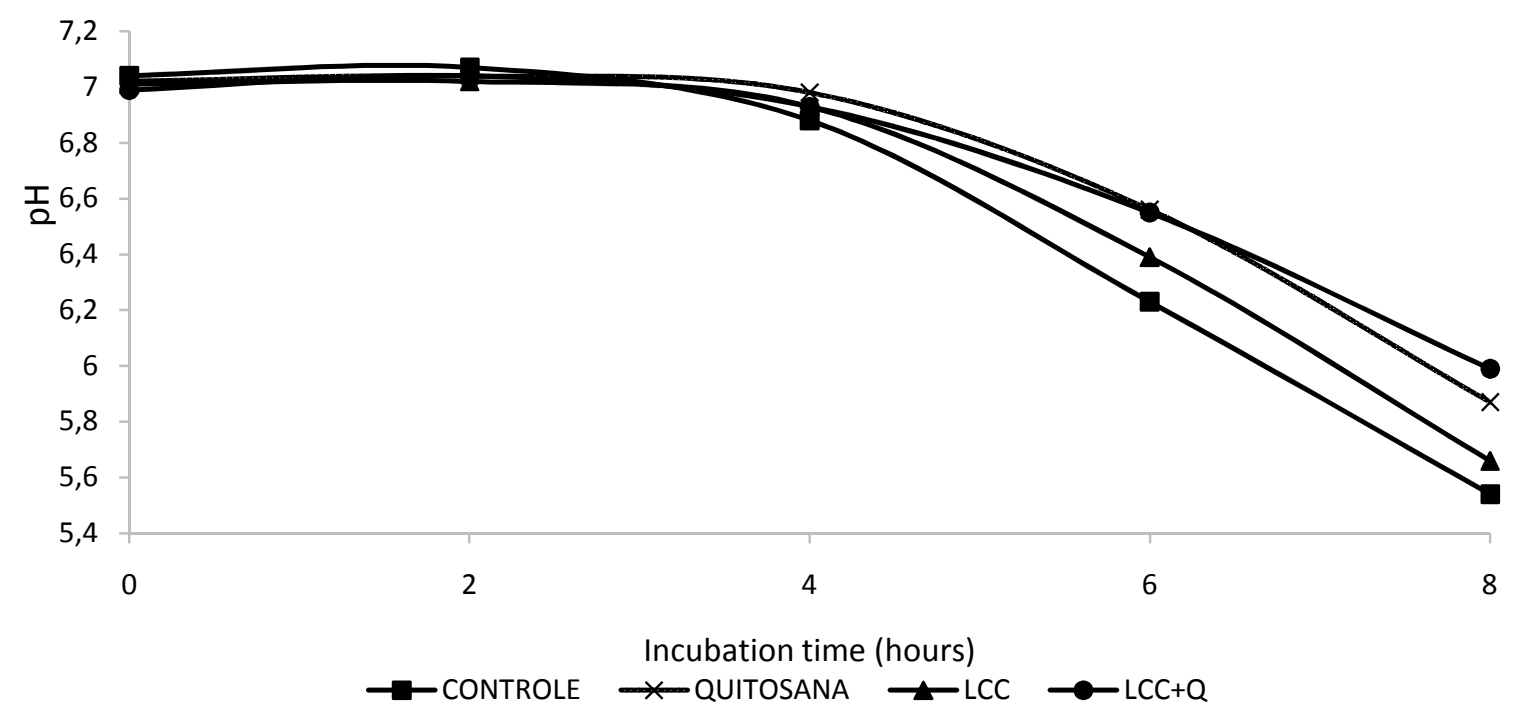

Figure 1:In vitro values of $\mathrm{pH}$ of the ruminal fluid over the collection times.

Control: $Y=-0.0339 x^{2}+0.0794 x+7.0486, r^{2}=0.99 ; L C C: Y=-0.034 x^{2}+0.1092 x+6.9923$, $\mathrm{r}^{2}=0.99$; Chitosan: $\mathrm{Y}=-0.0318 \mathrm{x}^{2}+0.1153 \mathrm{x}+6.9957, \mathrm{r}^{2}=0.98$; LCCQ: $\mathrm{Y}=-0.0266 \mathrm{x}^{2}+$ $0.0884 \mathrm{x}+6.9851, \mathrm{r}^{2}=0,99$.

Ruminal ammonia nitrogen (RAN) in the rumen fluid (Table 6; Figure 2) was influenced by the evaluated diets (P $<0.001)$, interaction ( $\mathrm{P}<0.001)$ and additives ( $\mathrm{P}<0.001)$. The highest mean values of RAN were in diets containing LCC, followed by chitosan treatment and finally Control, with a difference of $3.40 \%$.

Table 6. Values of Ruminal Ammonia Nitrogen obtained after collection in the digestor jars.

\begin{tabular}{lllllllll}
\hline & Diets & & & & & & \multicolumn{2}{l}{ P value } \\
\cline { 2 - 3 } \cline { 8 - 9 } Additive & $100: 0$ & $50: 50$ & $40: 60$ & $20: 80$ & Mean & SEM & L & Q \\
\hline Control & 10.05 & 15.53 & 10.68 & 24.32 & $15.14 \mathrm{C}$ & 1.5342 & 0.0001 & $<0.001$ \\
Chitosan & 10.24 & 19.01 & 21.50 & 27.17 & $19.47 \mathrm{~B}$ & 2.7563 & 0.0002 & 0.0011 \\
LCC & 10.13 & 22.84 & 18.43 & 37.52 & $22.22 \mathrm{~A}$ & 3.4734 & 0.0003 & 0.0005 \\
Q+LCC & 10.39 & 25.94 & 26.85 & 26.68 & $22.46 \mathrm{~A}$ & 3.6776 & 0.0054 & 0.0126 \\
\hline Mean & $10.20 \mathrm{c}$ & $20.82 \mathrm{~b}$ & $19.36 \mathrm{~b}$ & $28.92 \mathrm{a}$ & 19.86 & 2.110 & & \\
\hline
\end{tabular}

$\mathrm{L}=$ linear effect; $\mathrm{Q}=$ quadratic effect

Additive $(\mathrm{P}<0.001) ; \mathrm{F}: \mathrm{C}(\mathrm{P}<0.001)$; Interaction $(\mathrm{P}<0.001)$

Mean values followed by lowercase letters in the same row do not differ by Tukey's test.

Mean values followed by capital letters in the same column do not differ by Tukey's test.

All evaluated treatments presented RAN values close to $10 \mathrm{mg} / \mathrm{dL}$, with an increase as 
fermentation occurs $(15 \mathrm{mg} / \mathrm{dL}$, at hour 2$)$. All treatments presented values between $20 \mathrm{mg} / \mathrm{dL}$ and $23 \mathrm{mg} / \mathrm{dL}$, except for the control treatment, which remained at a concentration of $15 \mathrm{mg} / \mathrm{dL}$. From hour 6 onwards, only diets with LCC added exceeded $30 \mathrm{mg} / \mathrm{dL}(\mathrm{LCC}=34 \mathrm{mg} / \mathrm{dL}$ and $\mathrm{Q}+\mathrm{LCC}=39 \mathrm{mg} / \mathrm{dL}$ ), chitosan diets presented $24 \mathrm{mg} / \mathrm{dL}$. For hour 8 , the RAN values declined again, in the diets with chitosan and LCC, they remained above $26 \mathrm{mg} / \mathrm{dL}$.

$\mathrm{N}-\mathrm{NH}_{3}$ concentrations above $10(\mathrm{mg} / \mathrm{dL})$ favor the activity of microorganisms (STROBEL \& RUSSEL, 1986). The inclusion of chitosan did not cause such a significant effect on RAN, however,
Belanche et al. (2015)commented that chitosan raises ammonia concentration about 2 hours after feeding.

Beier\&Bertilsson (2011) suggest that chitosan deamination is necessary so that it can be degraded in the rumen by bacteria, however amine $\left(\mathrm{R}-\mathrm{NH}_{2}\right)$ degradation into ammonia $\left(\mathrm{NH}_{3}\right)$ explains the higher concentrations of ammonia in chitosan diets. Belanche et al. (2015) clarified that the extra nitrogen supply provided by chitosan deamination and the decrease in ammonia retention by ruminal microorganisms lead to higher ruminal ammonia peaks, instead of increasing food proteolysis.

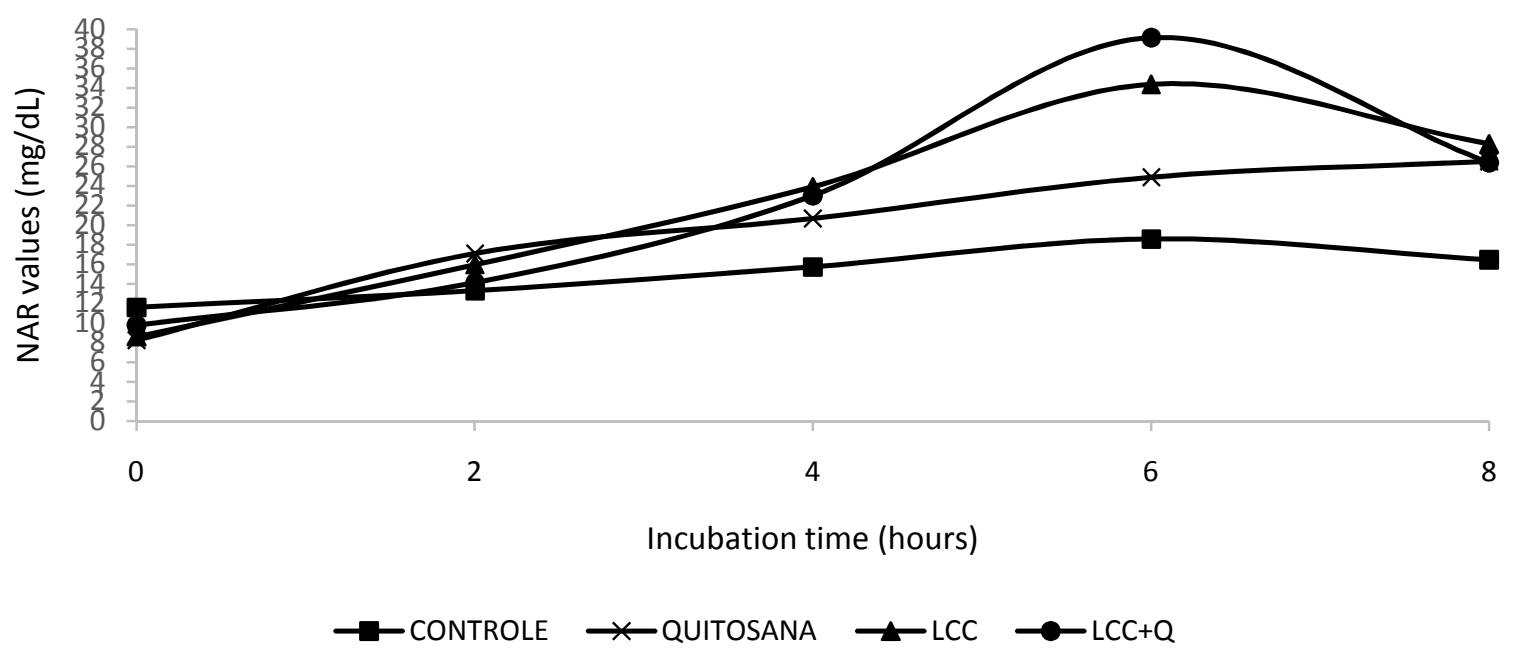

Figure 2. In vitro ruminal ammonia nitrogen contents of the ruminal fluid over thecollection time. Control: $\mathrm{Y}=-0.1302 \mathrm{x}^{2}+1.7879 \mathrm{x}+11.17, \mathrm{r}^{2}=0.87$; LCC: $\mathrm{Y}=0.4354 \mathrm{x}^{2}+10.6200 \mathrm{x}+$ 7.1944, $\mathrm{r}^{2}=0.91$; Chitosan: $\mathrm{Y}=-0.2466 \mathrm{x}^{2}+4.1847 \mathrm{x}+8.6471, \mathrm{r}^{2}=0.99$; LCCQ: $\mathrm{Y}=-$ $0.4818 x^{2}+6.7353 x+6.9697, r^{2}=0.75$

In order to compare the values of ammonia nitrogen, the amount of ammonia was compared along the collection time, and the highest values were found in diets with a higher proportion of concentrate, not corroborating Chapaval et al. (2008), who related the proportion of dietary concentrate with lower rumen ammonia concentrations.
According to Goiri et al. (2010a), chitosan decreases RAN concentrations, which is probably an indication of a lower crude protein deamination rate by ruminal microorganisms. Goiri et al. (2010b) also point out that the decrease in rumen ammonia concentration is due to the lower degradation of amino acids, compared to the microbial properties associated with 
chitosan, or increased use for microbial protein synthesis.

After in vitro evaluation of the inclusion of chitosan and cashew nut shell liquid in the ruminant diet, it was concluded that they have a positive influence on the DIVMS, DIVFDN and DIVPB ruminal parameters when used alone.

The addition of chitosan and/or LCC played a determining role in maintaining the $\mathrm{pH}$ and nitrogen of the ruminal fluid in cattle. The association of additives showed better results for $\mathrm{pH}$ and $\mathrm{RAN}$; bringing benefits to rumen fermentation.

\section{ACKNOWLEDGEMENTS}

To the Coordination for the Improvement of Higher Education Personnel - CAPES; Federal University of Grande Dourados for financial support and scholarships. The State University of Maringá; Foundation for the Development of Teaching, Science and Technology in Mato Grosso do Sul State (FUNDECT) and the National Council for Scientific and Technological Development - CNPq; for funding part of this work. In addition, the authors would like to thank Professor Antonio Ferriani Branco for donating the Technical Cashew Nut Shell Liquid; and Professor Claudia Andrea Lima Cardoso, for the characterization of the LCC used.

\section{REFERENCES}

ANASSORI, E.; DALIR-NAGHADEH, B.; PIR MOHAMMADI, R.; TAGHIZADEH, A.; ASRI-REZAEI, S.; MAHAM, M.; FARAHMAND-AZAR, S.; FARHOOMAND, P. Garlic: a potencial alternative for monensina as rumen modifier. Livestock Science, v.142, p.142276-287, 2011.

ASSOCIATION OF OFFICIAL ANALYTICAL CHEMISTRY - AOAC.
Official methods of analysis. 15th ed. Washington: AOAC International, 1990.

BEIER, S.; BERTILSSON, S. Uncoupling of chitinase activity and uptake of hydrolyses products in freshwater bacterioplankton. Limnol. Oceanogr. v.56, p.1179-1188, 2011. DOI: 10.4319/lo.2011.56.4.1179

BELANCHE, A.; RAMOS-MORALES, E.; NEWBOLD, C.J.; In vitro screening of natural feed additives from crustaceans, diatoms, seaweeds and plant extracts to manipulate rumen fermentation. Journal Science Food Agricuture, v.96, n.9, p.3069-3078, 2015.

CASALI, A.O.; DETMANN, E.; VALADARES FILHO, S.C. et al. Influência do tempo de incubação e do tamanho de partículas sobre os teores de compostos indigestíveis em alimentos e fezes bovinas obtidos por procedimentos in sito. R. Bras. Zootec., v.37, n.2, p.335342, 2008.

CHAPAVAL, L.; MELOTTI, L.; ROSSI JÚNIOR, P. et al. Relação volumoso concentrado sobre as concentrações ruminais de amônia, $\mathrm{pH}$ e ácidos graxos voláteis em vacas leiteiras mestiças. Rev. Bras. Saúde Prod. Anim., v.9, p.18-28, 2008.

DETMANN, E.; SOUZA, M.A.; VALADARES FILHO, S.C.; QUEIROZ, A.C.; BERCHIELLI, T.T.; SALIBA, E.O.S.; CABRAL, L.S.; PINA, D.S.; LADEIRA, M.M.; AZEVEDO, J.A.G. Métodos para análise de alimentos - INCT - Ciência Animal. Visconde do Rio Branco: Suprema, 2012. p.214, 2012.

DIAS, A.O.C.; GOES, R.H.T.B.;

GANDRA. J.R.; TAKIYA, C.; BRANCO, A,F,; JACAUNA, A.G.; OLIVEIRA, R.T.; SOUZA, C.J.S.; VAZ, M.S.M. Increasing 
doses of chitosan to grazing beef steers:

Nutrient intake and digestibility, ruminal fermentation, and nitrogen utilization.

Animal Feed Science Technology. v.225, p.73-80, 2017.

DIAZ, T.G.; BRANCO, A.F.; ITAVO, L.C.V.; SANTOS, G.T.; CARVALHO, S.T.; TEODORO, A.L.; OLIVEIRA, R.L. In vitro gas production kinetics and digestibility in ruminant diets with different levels of cashew nut shell liquid. Semina: Ciências Agrárias, v. 39, n. 4, p. 1669-1682, 2018.

GERACI, J.L.; GARCIARENA, A.D.; GAGLIO STRO, G.A.; BEAUCHEMIN, K.A.; COLOMBATTO, D. Plant extracts containing cinnamaldehyde, eugenol and capsicum oleoresin added to feedlot cattle diets: Ruminal environment, short term intake pattern and animal performance.

Animal Feed Science Technology. v.176, p.123-130, 2012.

GOIRI, I.; GARCIA-RODRIGUEZ, A.; OREGUI, L. M. Effects of chitosans on in vitro rumen digestion and fermentation of maize silage. Animal Feed Science and Technology, v.148, p.276-287, 2009 b.

GOIRI, I.; OREGUI, L.M.; GARCIARODRIGUEZ, A. Dose-response effects of chitosans on in vitro rumen digestion and fermentation of mixtures differing in forage-to-concentrate ratios. Animal Feed Science and Technology, v.151, p.215227, 2009a.

HOLDEN, L.A. Comparison of methods of in vitro dry matter digestibility for ten feeds. Journal of Dairy Science, Champaign, v.82, n.8, p.1791-1794, 1999. JACAÚNA, A.G. Avaliação in vitro da quitosana como aditivo em dietas para ruminantes. Dissertação (Mestrado em Zootecnia) - Universidade Federal da
Grande Dourados, Dourados-MS, p53, 2016.

MARTEN, G.C.; BARNES, R.F. Prediction of energy digestibility of forages with in vitro rumen fermentation and fungal enzyme systems. In: PIGDEN, W.J.; BALCH, C.C.; GRAHAM, M. (Eds.) Standardization of analytical methodology for feeds. Ottawa, IDRC, p.61-71, 1980.

OLIVEIRA, R.L.; CÂNDIDO, E.P.; LEÃO, A.G. A nutrição de ruminantes no Brasil. In: TÓPICOS ESPECIAIS EM CIÊNCIA ANIMAL I - COLETÂNEA DA I JORNADA CIENTÍFICA DA PÓS-GRADUAÇÃO EM CIÊNCIAS VETERINÁRIAS DA UNIVERSIDADE FEDERAL DO ESPÍRITO SANTO, 2012a.

RATCLIFF, J. From farm to fork: issues in food safety. In: WORLD CONFERENCE OF ANIMAL PRODUTION, REUNIÃO DA ASSOCIAÇÃO LATINOAMERICANA DE PRODUÇÃO ANIMAL, Porto Alegre. [Proceedings...] Porto Alegre: World Association of Animal Production: Asociacion Latinoamericana de Produccion Animal: Sociedade Brasileira de Zootecnia: Universidade Federal do Rio Grande do Sul, v.17, 2003.

SHINKAI, T.; ENISHI, O.; MITSUMORI, M. et al. Mitigation of methane production from cattle by feeding cashew nut shell liquid. Journal of Dairy Science, v.95 p.5308-5310, 2012.

SILVA, D.J.; QUEIROZ, A.C. Análise de alimentos: métodos químicos biológicos. Belo Horizonte: Fundação de Ensino e Pesquisa em Medicina Veterinária, 2 ed. 265p, 2002. 
STROBEL, H.J., RUSSELL, J.B. Effect of $\mathrm{pH}$ and energy spilling on bacterial protein syntheses by carbohydrate limited cultures of mixed rumen bacteria. Journal of Dairy Science, v.69, n.10, p.2947-2959, 1986.

TAGER, L.R.; KRAUSE, K.M. Effects of essential oils on rumen fermentation, milk production, and feeding behavior in lactating dairy cows. Journal of Dairy Science. v.94, p.2455-2464, 2011.

TANG, H.; ZHANG, P.; KIEFT, T. L.; RYAN, S. J.; BAKER, S. M.; WIESMANN, W. P.; ROGELJ, S. Antibacterial action of a novel functionalized chitosan-arginine against gram-negative bacteria. Acta

Biomaterialia, v.6, p.2562-2571, 2010.

TEKIPPE, J.A.; HRISTOV, A.N.; HEYLER, K.S.; CASSIDY, T.W.; ZHELJAZKOV, V.D.; FERREIRA, J.F.S.; KARNATI, S.K.; VARGA, G.A. Rumen fermentation and protozoal effects of Origanum vulgare L. leaves in lactating dairy cows. Journal of Dairy Science, v.94, p.5065-5079, 2011.

TILLEY, J.M.A.; TERRY, R.A. A twostage technique for the in vitro digestion of forage crops. Journal of the British Grassland Society, Oxford, v.18, n.2, p.104-111, 1963.

VAN DER WERF, H.M.G.;

MATHIJSSEN, E.W.J.M.; HAVERKORT, A.J. The potencial of hemp (Cannabis sativa L.) For sustainable fibre production: a crop physiological appraisal. Ann. Appl. Biol., v.129, p.109-123, 1996.

VAN SOEST, P. J.; ROBERTSON, J. B.; LEWIS, B. A. Symposium: carbohydrate methodology, metabolism, and nutritional implications in dairy cattle. Journal of Dairy Science, Champaign, v. 74, n. 10, p. 3583-3597, 1991
WATANABE, Y., SUZUKI, R., KOIKE, S., NAGASHIMA, K., MOCHIZUKI, M., FORSTER, R.; KOBAYASHI, Y. In vitro evaluation of cashew nut shell liquid as a methane-inhibiting and propionateenhancing agent for ruminants. Journal of Dairy Science, v.93, n.11, p. 5258-5267, nov.2010.

WENCELOVA M.; VARADYOVA Z.; MIHALIKOVA K.; KIŠIDAYOVÁ, S.; JALC, D. Evaluating the effects of chitosan, plant oils, and different diets on rumen metabolism and protozoan population in sheep. Turkish Journal of Veterinary and Animal Sciences, v.38, p.26-33, 2014.

YANG, W.Z.; BENCHAAR, C.; AMETAJ, B.N.; BEAUCHEMIN, K.A. Dose response to eugenol supplementation in growing beef cattle: Ruminal fermentation and intestinal digestion. Animal Feed Science and Technology, v.158, p.57-64, 2010. 